\title{
PROSEDUR PEMBAYARAN PAJAK PROGRESIF KENDARAAN RODA DUA PADA UPT BADAN PENDAPATAN DAERAH PROVINSI BALI KABUPATEN BULELENG
}

\author{
Kadek Pebi Surya Dewi \\ Jurusan Akuntansi Program Diploma III, \\ Universitas Pendidikan Ganesha Singaraja \\ Email: pebisurya02@gmail.com
}

\begin{abstract}
Abstrak
Penelitian ini bertujuan untuk mengetahui (1) prosedur pembayaran pajak progresif kendaraan roda dua pada UPT Badan Pendapatan Daerah Provinsi Bali Kabupaten Buleleng (2) dampak pajak progresif terhadap pemerintah dan wajib pajak. Subjek penelitian adalah Badan Pendapatan Daerah Provinsi Bali Kabupaten Buleleng sedangkan objeknya adalah prosedur pembayaran pajak progresif kendaraan roda dua pada badan pendapatan provinsi bali kabupaten buleleng. Penelitian ini menggunakan data kualitatif, sedangkan metode pengumpulan datanya adalah metode dokumentasi dan wawancara. Data yang diperoleh menggunakan data kualitatif yang menggambarkan prosedur pembayaran pajak progresif. Hasil penelitian ini menunjukan bahwa (1) prosedur pembayaran pajak progresif kendaraan roda dua dalam pembayaran pajak progresif masyarakat masih bingung maka dibuatkan prosedur wajib pajak datang sampai selesai pembayaran pajak progresif. (2) dampak pajak progresif terhadap pemerintah dan wajib pajak, dampak untuk pemerintah yaitu dampak positif meningkatkan pendapatan provinsi bali dan dampak negatif untuk pemerintah banyaknya wajib pajak yang tidak membayar pajak progresif dengan menjual kendaraannya.
\end{abstract}

Kata Kunci: Prosedur pembayran pajak progresif, dampak pajak progresif

Abstract

This study aims to determine (1) procedure of progressive tax payment of two-wheeled vehicle at UPT Badan Pendapatan Daerah Provinsi Bali Kabupaten Buleleng (2) the impact of progressive tax on government and taxpayers. The subject of this study is the Regional Income Board of Bali Province Buleleng District while the object is the procedure of progressive tax payment of two-wheeled vehicles in the revenue agency of Bali province Buleleng district. This research uses qualitative data, while the data were collected using documentation and interview method. Data obtained using qualitative data describing progressive tax payment procedure. The results of this study show that (1) Progressive tax payment procedure of two-wheeled vehicles in progressive tax payments of society is still confused then made the procedure from the taxpayer came to completion of progressive tax payment. (2) the impact of progressive tax on the government and taxpayers, the impact for the government is the positive impact of increasing the income of Bali province and the negative impact for the government of the number of taxpayers who do not pay progressive taxes by selling their vehicles. For taxpayers the positive impact of building adequate infrastructure. The negative impact of progressive taxes on society is more likely to have vehicles.

Keywords: Progressive tax payment procedure, progressive tax impact

\section{PENDAHULUAN}

Pajak adalah kontribusi wajib pajak kepada Negara yang terutang oleh orang pribadi atau badan yang bersifat memaksa berdasarkan undang-undang, dengan tidak mendapatkan imbalan secara langsung dan digunakan untuk keperluan Negara bagi sebesar-besarnya kemakmuran rakyat, pengertian pajak ini berdasarkan undang-undang No.28 Tahun 2007 tentang Ketentuan Umum dan Tata Cara Perpajakan. Pajak dibagi menjadi dua, yaitu Pajak Pusat dan Pajak Daerah, pajak yang dipungut oleh pemerintah 
pusat disebut dengan pajak pusat sedangkan pajak yang dipungut pemerintah daerah disebut pajak daerah.

Dalam Undang- Undang No. 28 tahun 2009 tentang pajak daerah terbagi menjadi dua yaitu pajak provinsi yang dipungut oleh pemerintah daerah tingkat provinsi dan pajak kabupaten/kota. Pajak provinsi terdiri dari dari Pajak Kendaraan Bermotor (PKB), Bea Balik Nama Kendaraan (BBNKB), Pajak Bahan Bakar Kendaraan Bermotor (PBBKB), Pajak Air Permukaan (PAP). Sedangkan pajak kabupaten/ kota terdiri dari Pajak Hotel, Pajak Restoran, Pajak Hiburan, Pajak Reklame, Pajak Parkir, Pajak Penerangan Jalan, Pajak Pajak Pengambilan Bahan Galian Golongan C.

Pajak memiliki peran penting selain berfungsi sebagai sumber pendapatan Negara juga memiliki fungsi distribusi (pemerataan). Pendapatan pajak penghasilan orang pribadi merupakan salah satu instrument dalam rangka mengatasi kesenjangan distribusi (pemerataan). Pendapatan antara orang (masyarakat) yang memiliki penghasilan pribadi di Indonesia mengenal tarif pajakprogresif dimana semakin tinggi penghasilan maka semakin tinggi pula tarif pajak penghasilannya.

Pajak progresif adalah pajak yang sistem pemungutannya dengan cara kenaikan presentase kena pajak yang harus dibayar sesuai dengan kebaikan objek pajak. Dalam sistem perpajakan di Indonesia, paling tidsk terdapat 2 (dua) jenis pajak yang menerapkan system pajak kendaraan bermotor.

Penerapan pajak progresif kendaraan bermotor bertujuan untuk mengurangi angka kemacatan yang disebabkan oleh padatnya kendaraan bermotor milik pribadi. Jika mengacu pada pasal 6 ayat (2) Undang-undang Republik Indonesia Nomor 28 tahun 2009 tentang pajak daerah dan retribusi daerah, kepemilikan kendaraan bermotor didasarkan atas nama dan /atau alamat yang sama. Akan tetapi dalam undang-undang tersebut tidak ada penjelesan terhadap "penguasaan"yang dimaksud dalam definisi pajak kendaraan bermotor.

Pemerintah Provinsi Bali melalui Dinas Pendapatan Provinsi Bali kembali menerapkan menerapkan pajak progresif yang mulanya mengacu pada Peraturan Daerah Nomor 1 tahun 2011 dan yang disempurnakan dengan Peraturan Daerah Nomor 8 tahun 2016

Pajak progresif roda dua baru diterapkan bulan September 2016 karena wajib pajak banyak lebih banyak memiliki kendaraan roda dua dibandingkan roda empat sehingga pemerintah lebih mengenakan pajak progresif roda dua.

Pajak Progresif yang mengacu pada Perda Nomor 1 tahun 2011 berbasis kartu keluarga (KK) namun pajak progresif yang mengacu pada Perda Nomor 8 tahun 2016 kini agak bersifat fleksibel karena bersandar pada kartu tanda penduduk (KTP). Selanjutnya pajak progresif ini berfungsi mengatur kepemilikan roda dua (2) dan roda empat (4) yang kedua dan seterusnya.

Keuntungan Pajak Progresif sesuai Perda Nomor 8 tahun 2016:

-Lebih fleksibel karena hanya berbasis KTP

-Pengenaan pajak untuk kepemilikan kedua ketiga dan seterusnya dimungkinkan tidak kena pajak progresif karena kepemilikannya mungkin bisa diatas namakan ke saudara yang lain

-Tidak membutuhkan Kartu Keluarga (KK)

Kepemilikan kendaraan bermotor tersebut didasarkan atas nama dan alamat yang sama sesuai dengan identitas diri yang ditunjukan dengan Kartu Tanda Penduduk. Selain itu untuk kepemilikan kendaraan bermotor roda seperti angkutan umum, ambulans, pemadam kebakaran, lembaga social keagaman, konsulat, pemerintah/pemerintah daerah, BUMN/BUMD, TNI dan POLRI tidak di kenakan pajak secara progresif.

Pengenaan tarif pajak progresif bertujuan untuk mengurangi angka kemecaten yang ada dibali yang disebabkan padatnya kendaraan bermotor pribadi. Tetapi karena masyarakat masih belum banyak yang mengerti sepenuhnya tentang pajak progresif ini, menyebabkan tidak sedikit masyarakat yang kebingungan untuk membayar pajak progresif untuk memudahkan pembayaran pajak progresif maka perlu adanya prosedur. Prosedur terhadap pembayaran pajak progresif sangat di perlukan agar didalam menjalakan 
kegiatan operasionalnya agar masyarakat lebih mudah membayar pajak progresif di Badan Pendapatan Provinsi bali Kabupaten Buleleng/SAMSAT BULELENG. Berdasarkan latar belakang tersebut maka penelitian ini dilaksanakan dengan mengambil judul "PROSEDUR PEMBAYARAN PAJAK PROGRESIF DI BADAN PENDAPATAN PROVINSI BALI KABUPATEN BULELENG" Berdasarkan latar belakang di atas, maka rumusan masalah yang diangkat adalah Bagaimana prosedur pembayaran Pajak Progresif kendaraan (Roda Dua) pada UPT Bapenda Provinsi Bali Kabupaten Buleleng? dan Bagaimana dampak pajak progresif terhadap pemerintah dan wajib pajak?. Adapun Tujuan yang hendak dicapai dalam penelitian ini yaitu Untuk mengetahui prosedur pembayaran pajak progresif kendaraan (Roda Dua) pada UPT Bapenda Daerah Provinsi Bali Di Kabupaten Buleleng dan Untuk mengetahui dampak pajak progresif terhadap pemerintah dan wajib pajak.

\section{METODE PENELITIAN}

Adapun rancangan penelitian yang digunakan adalah penelitian deskritif. Pada Badan Pendapatan Daerah Provinsi Bali di Kapubaten Buleleng. Jenis data yang digunakan dalam penelitian ini menggunakan data kualitatif. Data kualitatif yaitu berupa dokumen-dokumen penting atau catatan-catatan lainnya yang mendukung dalam pengolahan data nantinya menenai prosedur pembayaran pajak Progresif kendaraan roda dua di Badan Pendapatan Daerah Provinsi Bali di Kabupaten Buleleng. Data-data tersebut diambil dan dikumpulkan dengan metode wawancara dan dokumtasi. Wawancara dilakukan kepada pihak-pihak tertentu dalam SAMSAT yang tentunya berkaitan langsung dengan pajak progresif.

Dari data yang telah terkumpul akan dianalisis dengan menggunkan teknik menggambarkan keadaan perusahaan dan menguraikan data kualitatif mengenai prosedur pembayaran pajak progresif kendaraan roda dua pada Badan Pendapatan Daerah Provinsi Bali di Kabupaten Buleleng.

\section{HASIL DAN PEMBAHASAN}

Pajak progresif berlaku pada kendaraan roda dua dimulai pada juni 2016.Tujuan dari pajak progresif ini secara umum yaitu mengantisifasi kemacetan dengan mengontrol jumlah kendaraan yang ada di buleleng dan menerapkan asas keadilan. Pajak progresif kendaaran bermotor roda dua di rencang sedemikian rupa untuk dapat mencapai tujuan namun tidak mengurangi jumlah pendapatan pajak kendaraan bermotor tersebut. Sebagaimana telah disebutkan, pajak progresif kendaraan bermotor diawal di penerapannya dikenakan berdasarkan KK atau kartu keluarga, dimana terdapat nama dan/atau alamat yang sama dalam satu keluarga. Sehingga wajib pajak yang memiliki kendaraan bermotor lebih dari satu unit jika kendaraan itu terdaftar dialamat yang sama, maka akan dikenakan pajak progresif.

Namun penerapan pajak progresif berdasarkan KK (kartu keluarga) setelah dievaluasi selama ini ternyata mengalami kendala. Adapun kendala-kendala yang dialami selama selama penerapan pajak progresif ini yaitu:

1. Masyarakat membeli kendaraan diluar bali.

2. Dirasa ada pembatasan hak dalam kenginan untuk membeli motor

3. Tidak sedikit masyarakat yang meminjam KK (kartu keluarga) orang lain untuk mendaftarkan sebagai pemilik kendaraan.

Setelah diakannya evaluasi penerapan pajak progresif kendaraan bermotor berdasarkan KK ini, maka per 3 oktober 2016 pajak progresif kendaraan bermotor diterapkan berdasarkan KTP. Maksudnya adalah pajak progresif akan berlaku jika masyarakat memiliki kendaraan 
roda dua lebih dari satu atas nama dan alamat yang sama sesuai dengan identitas diri yang ada dalam KTP. Dasar pengenaan pajak progresif kendaraan bermotor ini adalah:

1. Undang-undang No 28 Tahun 2009 tentang pajak daerah dan retrebusi daerah

2. Perda Provinsi Bali Nomor 8 Tahun 2016 tentang pajak daerah

3. Ketentuan Dalam Pasal 7 Ayat (1) Peraturan Daerah Nomor 8 Tahun 2016 Tentang Perubahan Daerah Provinsi Bali. Nomor Tahun 2011 Tentang Pajak Daerah

Maka jika wajib membayar pajak progresif wajib pajak cukup membawa persyaratan (data/dokumen) yang diperlukan sebagai berikut :

1. Meliputi fotocopy identitas diri yaitu:

b. Untuk penduduk Bali harus menggunakan 1 lembar fotocopy kartu tanda penduduk (KTP)

c. Untuk penduduk luar Bali menggunakan 1 lembar fotocopy kartu tanda penduduk (KTP) serta fotocopy KIPEM Bali

d. Untuk warga Negara asing menggunakan 1 lembar fotocopy passport serta fotocopy KITAS/KITAP

e. $\quad 1$ lembar surat kuasa asli yang bermaterai cukup bagi yang mewakilkan.

Prosedur pembayaran pajak progresif kendaraan roda dua pada UPT Badan Pendapatan Daerah Provinsi Bali di Kabupaten Buleleng.

Dalam Prosedur pembayaran pajak progresif kendaraan roda dua pada Badan Pendapatan Daerah Provinsi Bali di Kabupaten Buleleng sudah berjalan baik dan memadai sesuai dengan ketentuan teori yang ada. Adapun prosedur dari pajak progresif sebagai berikut:

1. Pertama kali wajib pajak menuju loket pendaftaran kemudian petugas pendaftaran memberikan informasi mengenaai urut milik kendaraan dengan menginput nomor polisi serta nomor KTP wajib pajak pada menu informasi. Setelah informasi urut milik muncul, petugas pendaftaran mengkonfirmasikan urut milik kendaraan kepada wajib pajak. Apabila wajib pajak tidak setuju dengan urut milik kendaraan, wajib pajak diarahkan menuju loket pendataan progresif dahulu.

2. Setelah wajib pajak melakukan pendataan progresif, wajib pajak kembali menuju ke loket pendaftaran.

3. Apabila tidak ditemukan nomor KTP / nomor passport di sistem aplikasi, maka petugas pendaftaran menginput data KTP / passport wajib pajak tersebut sesuai dengan dokumen identitas yang dibawa.

4. Pada saat pendaftaran transaksi samsat, nomor KTP wajib diinput. Nama pada nomor KTP yang diinput harus sama dengan nama pada data kendaraan. Nama di KTP dibandingkan dengan nama di kendaraan dengan metode menghilangkan gelar, pemetaan nama bali serta menghilangkan tanda baca.

5. Apabila nama pada nomor KTP yang diinput sama dengan nama pada data kendaraan dapat lanjut proses pendaftrannya, namun apabila dianggap nama berbeda maka kemudian dilakukan pengecekan tahap berikutnya.

6. Pengecekan nama tahap berikutnya akan mengecek nama pada nomor KTP yang diinput dengan nama pada data kendaraan dengan metode mencari salah satu kata inti dengan mengabaikan nama bali, menghilangkan tanda baca.

7. Apabila ditemukan salah satu kata inti pada nama di KTP dengan nama di kendaraan, maka diperbolehkan untuk melakukan approval level 2. Approval level 2 diberikan untuk menyetujui pendaftaran untuk kondisi data nama yang tidak persis sama karena adanya penyingkatan nama maupun gelar yang belum terpetakan. Approval level 2 diberikan di seluruh petugas pendaftran dilayanan samsat, namun approval level 2 hanya dapat dilakukan di UPT Samsat online dimana approval level 2 itu terdaftar. 
8. Apabila tidak ditemukan salah satu kata inti atau dengan kata lain nama di KTP sangat berbeda dengan nama kendaraan, maka wajib balik nama atau dapat dilakukan approval dengan alasan khusus menggunakan approval level 1 . Approval 1 level 1 diberikan kepada pejabat kepoliaisan yang ditunjuk.

9. Approval level 1 maupun level 2 berupa memasukan username, password serta alasan dilakukan approval.

10. Nama kuasa serta nomor HP juga wajib diinput oleh petugas pendaftran.

11. Saat proses pendaftran berhasil, lanjut proses penentapan.

12. Petugas penetapan ataupun petugas kasir wajib memberikan informasi urutan kepemilikan berdasarkan urut milik yang tertera pada SPPKB sebelum wajib pajak melakukan pembayaran untuk menghindari komplain setelah pembayaran.

Dari prosedur pembayaran pajak progresif kendaraan roda dua diatas dapat disimpulkan bahwa data yang di siapkan wajib pajak adalah KTP (Kartu Tanda Penduduk), STNK asli, BPKB dan surat kuasa jika dikuasakan. Kemudian wajib pajak melakukan menuju loket progresif dan kembali menuju loket pendaftran setelah dari sana wajib wajib menuju loket kasir setelah melakukan pembayaran kemeudian menuju loket penetapan dan yang terakhir ke loket pengambilan. Dengan demikian prosedur tersebut sudah diimplementasikan dengan baik oleh samsat sesuai dengan teori dan wajib pajak sudah merasa mampu untuk melakukan prosedur pembayaran pajak progresif kendaraan roda dua.

\section{Dampak Pajak Progresif Terhadap Pemerintah Dan Wajib Pajak}

Pajak progresif adalah pajak yang sistem pemungutannya dengan cara menaikan persentase kena pajak yang harus dibayar sesuai dengan kenaikan objek pajak. Pajak progresif yang baru ada sejak tahun 2016 lalu, yang diterapkan untuk mengurangi kemacetan di bali. Pajak progresif memiliki dampak terhadap pemerintah dan wajib pajak adalah sebagai berikut:

1. Dampak terhadap pemerintah

-Dampak positif dari pajak progresif untuk pemerintah yaitu menekan volume kendaran dan mengurangi angka kemacetan yang disebabkan oleh kendaraan pribadi dan untuk meningkatkan pendapatan asli daerah di provinsi Bali, karena dengan meningkatnya jumblah pajak yang harus dibayarkan oleh wajib pajak, tentu saja berpengaruh terhadap pendapatan provinsi bali jika pajak ini meningkat setiap tahunnya maka akan digunakan untuk membangun prasarana jalan raya dan pengadaan transportasi.

- Dampak negatif .dari pajak progresif untuk pemerintah yaitu banyaknya wajib pajak yang tidak membayar pajak progresif dengan menjual kendaraannya.

2. Dampak terhadap wajib pajak/ masyarakat.

- Dampak positif pajak progresif yang dirasakan masyarakat/wajib pajak adalah terbangunnya prasarana seperti jalan raya dan transportasi. Jika pajak ini terlealisasikan dengan baik maka jalan-jalan akan nyaman didilalui oleh masyarakat dan tersediannya transportasi umum yang nyaman digunakan oleh masyarakat.

- Dampak negatif pajak progresif untuk masyarakat adalah masyarakat jadi lebih berfikir untuk memiliki banyak kendaraan untuk perorangnya karena jika memiliki kendaraan lebih dari satu maka akan membayar pajak lebih besar dan untuk masyarakat/ wajib pajak yang memiliki usaha dibidang penjualan kendaraan bermotor maka akan mengalami penurunan penjualan yang disebabkan oleh adanya pajak progresif.

\section{Simpulan dan Saran}

Berdasarkan hasil penelitian, peneliti menyimpulkan bahwa Hasil penelitian ini menunjukan bahwa (1) prosedur pembayaran pajak progresif kendaraan roda dua dalam pembayaran pajak progresif masyarakat masih bingung maka dibuatkan prosedur wajib pajak datang sampai selesai pembayaran pajak progresif. (2) dampak pajak progresif 
terhadap pemerintah dan wajib pajak, dampak untuk pemerintah yaitu dampak positif meningkatkan pendapatan provinsi bali dan dampak negatif untuk pemerintah banyaknya wajib pajak yang tidak membayar pajak progresif dengan menjual kendaraannya.Karena itu pemerintah perlu memeprhatikan pajak progresif ini. Bagi penelitian selanjutkan penelitian tentang pajak progresif tidak hanya diteliti dari sisi dampaknya saja tetapi juga bagaimana dalam perancangan kebijakannya.

\section{DAFTAR PUSTAKA}

------. 2016. Standar Operasional Prosedur (SOP) Pengenaan Pajak Progresif untuk Kendaraan Bermotor. Dinas Pendapatan Provinsi Bali.

--------------. Uraian Jabatan. UPT Badan Pendapatan Daerah Provinsi Bali Kabupaten Buleleng.

Bermotor

Dispenda. 2017 Informasi Layanan Pajak, tersedia

http://Www.Dispenda.Baliprov.Go.Id/Id/Informasi-Layanan-Publik-Tentang-Pajak-Progresif

Diakses Tanggal 07/03/2017

Mardiasmo. 2011, Perpajakan Edisi Revisi 2011, Andi, Yogyakarta.

Munawir S. 2002, Perpajakan, Edisi Revisi, Liberty, Yogyakarta.

Pada http://www.qolbunhadi.com/pengertian-fungsi-jenis-pajak/, diakses ditanggal $07 / 03 / 2016$

Penyelenggaraan Sistem Administrasi Manunggal Satu Atap Kendaraan

Peraturan Daerah Nomor 8 Tahun 2016 tentang penerapan pajak progresif.

Peraturan Daerah Provinsi Bali Nomor 1 Tahun 2011 yang disempurnakan dengan

Peraturan Presiden Republik Indonesia. Nomor 5 Tahun tahun 2015 tentang

Pohan, CA 2011, Optimazing Corporate Tax Management, Bumi Aksara, Jakarta

Qolbunhadi. 2016, pengertian-fungsi-jenis-pajak, tersedia

Resmi, Sitti 2009, Perpajakan : Teori dan Kasus, Jakarta : Salemba Empat.

Rineka Cipta Waluyo. 2009 . Akuntansi Pajak . Jakarta . Penerbit : Salemba Empat

Suandy, Erly, 2006, Perpajakan, Edisi Pertama, Jakarta, Salemba Empat.

Suharsimi Arikunto . 2010. Prosedur Penelitian Suatu Pendekatan Praktek. Jakarta. Penerbit:

Undang-undang nomor 34 tahun 2000 tentang perubahan undang-undang nomor 18 tahun 1997 tentang pajak daerah dan retribusi daerah

Undang-Undang Republik Indonesia Nomor 18 Tahun 1997 Tentang Pajak Daerah Dan Retribusi Daerah

Undang-Undang Republik Indonesia Nomor 28 Tahun 2009 tentang pajak daerah dan retribusi daerah beserta penjelasannya 